doi: 10.15407/ukrbotj73.01.090

\title{
Н.В. КАПЕЦЬ
}

Інститут ботаніки імені М.Г. Холодного НАН України

вул.Терещенківська, 2, м. Київ, 01004, Україна

kapets_n@ukr.net

\section{НОВІ ТА РІДКІСНІ ДЛЯ УКРАЇНИ ЛІХЕНОФІЛЬНІ ГРИБИ}

Kapets N.V. New and rare to Ukraine lichenicolous fungi. Ukr. Bot. J., 2016, 73(1): 90-92.

M.G. Kholodny Institute of Botany, National Academy of Sciences of Ukraine

2, Tereshchenkivska Str., Kyiv, 01004, Ukraine

Abstract. A new to Ukraine species (Lichenothelia tenuissima Henssen) and five rare species (Marchandiomyces aurantiacus (Lasch) Diederich \& Etayo, Monodictys epilepraria Kukwa \& Diederich, Taeniolella punctata M.S. Christ. \& D. Hawksw., Sclerococcum sphaerale (Ach.) Fr., Lichenodiplis lecanorae (Vouaux) Dyko \& D. Hawksw.) of lichenicolous fungi are reported. Descriptions of the species Lichenothelia tenuissima and Taeniolella punctata as well as the localities, data on ecology and taxonomic notes for the above mentioned species are provided.

Key words: Lichenothelia tenuissima, rare lichenicolous fungi, Central Polissya

Вивчення ліхенофільних грибів на території УКраїни розпочато в $90-\mathrm{x}$ роках минулого століття й залишається одним із пріоритетних і перспективних напрямків вітчизняної мікології. Посилений інтерес дослідників до цієї групи організмів зумовив стрімке зростання кількості відомостей щодо їх видового складу й особливостей поширення на території України. Опрацювавши колекції лишайників із Центрального Полісся, ми виявили один новий (Lichenothelia tenuissima Henssen.) і п'ять рідкісних для України видів ліхенофільних грибів (Marchandiomyces aurantiacus (Lasch) Diederich \& Etayo, Monodictys epilepraria Kukwa \& Diederich, Taeniolella punctata M.S. Christ. \& D. Hawksw., Sclerococcum sphaerale (Ach.) Fr., Lichenodiplis lecanorae (Vouaux) Dyko \& D. Hawksw.), два з яких (Monodictys epilepraria та Taeniolella punctata) вперше наводяться для рівнинної частини України. Подаємо морфологічні описи, відомості щодо екологічних особливостей вищевказаних видів.

Lichenothelia tenuissima Henssen, Bibliotheca Lichenologica 25: 262 (1987).

Новий для України вид.

Слань чорна, ареольована, ареоли розсіяні до частково згрупованих, 80-160 мкм завширшки, мікрослань часто має столони. Макроконідії кулясті й еліпсоїдні, 9,5-10,5 мкм. Аскома випукла, до 150 мкм завширшки; гаматецій параплектенхіматозний, амілоїдний; сумки мішкоподібні, 3335×16-18 мкм, 8-спорові; спори 2-клітинні, безбарвні, з часом стають коричневими, бородавчасті, (C) Н.В. КАПЕЦЬ, 2016
11,0-14,5 × 6,5-7,5 мкм. Пікнідії 40-45 мкм завширшки, конідії - 2,0-2,5 × 6,5-7,5 мкм (Henssen, 1987).

Екологічні особливості: на виходах різноманітних гірських порід або на сланях епілітних лишайників.

Поширення в Україні: Житомирська обл., Коростишівський $\mathrm{p}-\mathrm{H}, \quad$ затоплений гранітний кар'єр в околицях м. Коростишева, 50¹8'53.09"N $29^{\circ} 05^{\prime} 37.66^{\prime \prime E}, 189$ м над р.м., 22.07.2015, Н. Капець ( $K W$ - $L$ 70511); м. Коростишів, на виходах гранітів уздовж правого берега р. Тетерів, $50^{\circ} 18^{\prime} 50.76 " \mathrm{~N}$ $29^{\circ} 04^{\prime} 27.08^{\prime \prime}$, 159 м над р.м., 22.07.2015, Н. Капець (KW-L 70512).

Загальне поширення: США, Канада, Австрія, Росія (Hawkswort, 1979).

Marchandiomyces aurantiacus (Lasch) Diederich \& Etayo, Mycotaxon 60: 421 (1996).

Поширення в Україні: Житомирська обл., Народицький р-н, Природний заповідник «Древлянський», околиці с. Звіздаль, на слані Physcia stellaris (L.) Nyl., 19.08.2015, Н. Капець (KW-L 70521).

Таксономічна примітка: Marchandiomyces aurantiacus склероціальна анаморфа виду Marchandiobasidium aurauntiacum Dierderich \& Schultheis. Детальний опис виду та відомості про перші знахідки його на території України наведено в праці Л.М. Гавриленко з колегами (Havrylenko et al., 2009). Досі були відомі знахідки Marchandiobasidium aurauntiacum із Херсонської обл. (Havrylenko et al., 2009, Khodosovtsev, Naumovych, 2009; Havrylenko, 2011; Khodosovtsev, Khodosovtseva, 2014). Koнідіомата M. aurantiacus розвивається на сланях лишайників родів Phaeophyscia Moberg, Physcia (Schreb.) Michx. та Xanthoria (Fr.) Th. Fr., більш-менш поверхнева, помаранчева. 
Monodictys epilepraria Kukwa \& Diederich, The Lichenologist 37(3): 217 (2005)

Поширення в Україні: Житомирська обл., м. Коростишів, виходи гранітів уздовж правого берега p. Тетерів, 50 $18^{\prime} 50.76^{\prime \prime} \mathrm{N} 29^{\circ} 04^{\prime} 27.08^{\prime \prime} \mathrm{E}, 159$ м над р.м., на слані Lepraria Ach. sp., 22.07.2015, Н. Капець ( $K W-L$ 70513). Житомирський р-н, виходи гранітів уздовж правого берега р. Бобрівка, неподалік санаторію «Дениші», на слані Lepraria membranacea (Dicks.) Vain., 14.06.2015, Н. Капець (KW-L 70522).

Таксономічна примітка: опис виду та перші відомості про його поширення в Україні опубліковано у праці Я. Вондрака $з$ колегами (Vondrak et al., 2010). Раніше вид наводився лише для території Карпат, а отже, наша знахідка є першою для рівнинної території України.

Taeniolella punctata M.S. Christ. \& D. Hawksw., Bulletin of the British Museum for Natural History 6(3): 257 (1979).

Досі для території України вид вказували тільки для Східних Карпат і Прикарпаття (Kondratyuk et al., 2003), а отже, ця знахідка - перша для рівнинної території України. Оскільки так і не був опублікований опис виду українською мовою, ми подаємо його нижче.

Паразитує на слані Graphis scripta (L.) Ach. Koлонії розкидані по слані господаря, крапкоподібні, коричневі. Міцелій занурений, світло-коричневий, 4-6 мкм завширшки, Конідіофори поверхневі, прямі, з гладенькими, товстими стінками, від світло- до темно-коричневих, 20-40(60) $\times$ 5-8 мкм; зібрані в маленькі пучки, зазвичай утворюють 1-3 розгалуження при основі. Конідіогенні клітини проліферовані, субциліндричні, з піхвоподібними стінками, що залишаються на конідіофорі після відокремлення конідій. Конідії аерогенні, еліпсоїдні, бочкоподібні, з обома усіченими кінцями, зібрані в ланцюги, 10,0-12,5 мкм, з 1-2 септами, іноді звужені в ділянці септ (Hawkswort, 1979).

Taeniolella punctata схожа на T. pulvillus (Berk. \& Br.) M. B. Ellis, що зростає на корі Quercus robur L., останній відрізняється видовженими конідіофорами з 2-11 септами, 25-90 × 7-9 мкм.

Поширення в Україні: Житомирська обл., Житомирський р-н, буковий ліс між селами Тригір'я та Висока Піч, 50¹1'10.13"N 28²1'47.81"E, 220 м над p.м., на слані Graphis scripta (L.) Ach., що зростає на корi Fagus sylvatica L., 12.06.2015, Н. Капець ( $K W-L$ 70530).
Sclerococcum sphaerale (Ach.) Fr., Scleromyceti suecici no 179: no. 179 (1821).

Поширення в Україні: Житомирська обл., м. Коростишів, виходи гранітів уздовж правого берега р. Тетерів, 50²' $18^{\prime} 50.76^{\prime \prime} \mathrm{N} 29^{\circ} 04^{\prime} 27.08^{\prime \prime} \mathrm{E}$, 158,94 м над р.м., 22.07.2015, Н. Капець $(K W-L$ 70516).

Таксономічна примітка: Sclerococcum sphaerale раніше наводився для Запорізької обл., опис виду подано у праці С.Я. Кондратюка з колегами (Kondratyuk et al., 1999).

Lichenodiplis lecanorae (Vouaux) Dyko \& D. Hawksw., The Lichenologist 11(1): 52 (1979).

Поширення в Україні: Житомирська обл., м. Коростишів, насадження Betula pendula Roth уздовж лівого берега р. Тетерів, неподалік вул. Східної, $50^{\circ} 20^{\prime} 25,99^{\prime \prime} \mathrm{N} 29^{\circ} 04^{\prime} 35,67^{\prime \prime E}, 153$ м над р.м., на слані Lecanora saligna (Schrad.) Zahlbr., шо зростає на кopi Betula pendula Roth., 2014 p., Н. Капець ( $K W-L$ 70515).

Таксономічна примітка: опис виду міститься у праці С.Я. Кондратюка 3 колегами (Kondratyuk et al., 1999). Вид наводиться для Чорноморського заповідника, Національного природного парку «Шацький» і Біосферного заповідника «Асканія-Нова» (Kondratyuk, 1999; Pirohov, 2013; Khodosovtsev, Khodosovtseva, 2014).

\section{СПИСОК ЛІТЕРАТУРИ}

Hawkswort D. L. The lichenicolous Hyphomycetes, Bull. of the British Museum for Natural History, 1979, 6(3): 183-301.

Havrylenko L.M., Khodosovtsev O.E., Naumovych H.O., Chornomorski Bot. J., 2009, 5(4): 609-611. [Гавриленко Л.М., Ходосовцев О.Е., Наумович Г.О. Marchandiobasidium aurantiacum (Lasch) Diederich \& Schultheis - новий для України вид ліхенофільного гриба // Чорноморськ. бот. журн. - 2009. - 5(4). - С. 609-611].

Havrylenko L.M. In: Karazinski pryrodoznavchi studii: materialy mizhnarodnoi naukovoi konferentsii, Kharkiv, 2011, pp. 25-27. [Гавриленко Л.М. Ліхенобіота балки Дудчани (Херсонська область, Нововоронцовський р-н) // Каразінські природознавчі студії: мат-ли міжнар. наук. конф. (Харків, 1-4 лютого, 2011 р.) - Харків, 2011. - C. 25-27].

Henssen A. Lichenothelia genus of microfungi on rocks, Progress and Problems in Lichenology in the Eighties. Bibl. Lichenol, 1987, 25: 257-293.

Pirohov M. Management of Environmental Protection in Forests, 2013, 7: 94-108. [Пирогов Н. Лишайники и лихенофильные грибы Шацкого Национального природного парка (Украина) // Zarzadzanie Ochrona przyrody w lasach. - 2013. - 7. - C. 94-108].

Khodosovtsev O., Khodosovtseva J. Chornomorski Bot. J., 2014, 10(4): 515-525. [Ходосовцев О.Є., Ходосовцева Ю.А. Лишайники та ліхенофільні гриби дендрологічного парку біосферного заповідника «Асканія- 
Нова» ім. Ф.Е. Фальц-Фейна // Чорноморськ. бот. журн. - 10(4). - C. 515-526].

Kondratyuk S.Ya., Andrianova T.V., Tykhonenko Iu.Ia. Vyvchennia riznomanitnosti mikobioty Ukrainy (likhenofilni, septoriievi ta puktsyniievi hryby), Kyiv: Phytosociocentre, 1999, 112 pp. [Кондратюк С.Я., Андріанова Т.В., Тихоненко Ю.Я. Вивчення різноманітності мікобіоти України (ліхенофільні, септорієві та пукцинієві гриби). - К.: Фітосоціоцентр, 1999. - 112 c.].

Kondratyuk S.Ya., Popova L.P., Lackovičová Á.A., Pišut I. A catalogue of Eastern Carpathian Lichens, Kyiv; Bratislava, M.N. Kholodny Institute of Botany, 2003, 264 pp.

Kukwa M., Diederich P. Monodictys epilepraria, a new species of lichenicolous hyphomycetes on Lepraria, The Lichenologist, 2005, 37(3): 217-220.

Vondrak J., Palitse Z., Khodosovtsev O., Postoialkin S. Chornomorski Bot. J., 2010, 6(1): 6-34. [Вондрак Я., Паліце 3., Ходосовцев А., Постоялкін С. Доповнення до різноманіття рідкісних або маловідомих лишайників та ліхенофільних грибів Українських Карпат // Чорноморськ. бот. жуурн. - 2010. - 6(1). - С. 6-34].

Рекомендує до друку I.О. Дудка
Капець Н.В. Нові та рідкісні для України ліхенофільні гриби. - Укр. ботан. журн. - 2016. - 73(1): 90-92.

Інститут ботаніки імені М.Г. Холодного НАН України вул.Терещенківська, 2, м. Київ, 01004, Україна

Наведено дані щодо поширення одного нового для України (Lichenothelia tenuissima Henssen) і п'яти рідкісних (Marchandiomyces aurantiacus (Lasch) Diederich \& Etayo, Monodictys epilepraria Kukwa \& Diederich, Taeniolella punctata M.S. Christ. \& D. Hawksw., Sclerococcum sphaerale (Ach.) Fr., Lichenodiplis lecanorae (Vouaux) Dyko \& D. Hawksw.) видів ліхенофільних грибів. Подано повні описи видів Lichenothelia tenuissima і Taeniolella punctata, перелік їхніх місцезнаходжень, відомості щодо екологічних особливостей і таксономічні примітки.

Ключові слова: Lichenothelia tenuissima, рідкісні види ліхенофільних грибів, Центральне Полісся.

Капец Н.В. Новые и редкие для Украины лихенофильные грибы. - Укр. ботан. журн. - 2016. - 73(1): 90-92.

Институт ботаники имени Н.Г. Холодного НАН Украины ул. Терещенковская, 2, г. Киев, 01004, Украина

Приведены данные о распространении нового для Украины (Lichenothelia tenuissima Henssen) и пяти редких (Marchandiomyces aurantiacus (Lasch) Diederich \& Etayo, Monodictys epilepraria Kukwa \& Diederich, Taeniolella punctata M.S. Christ. \& D. Hawksw., Sclerococcum sphaerale (Ach.) Fr., Lichenodiplis lecanorae (Vouaux) Dyko \& D. Hawksw.) видов лихенофильных грибов. Даны полные описания видов Lichenothelia tenuissima и Taeniolella punctata, приведены их местонахождения, сведения про экологические особенности и таксономические примечания.

Ключевые слова: Lichenothelia tenuissima, редкие виды лихенофильных грибов, Центральное Полесье.

НОВІ ВИДАННЯ

Якубенко Б.Є., Попович С.Ю., Григорюк І.П., Устименко П.М. Геоботаніка: тлумачний словник: Навч. посібник. 3-тє видання / Національний університет біоресурсів та природокористування, Інститут ботаніки імені М.Г. Холодного НАН України. - К.: Фітосоціоцентр, 2015. - 421 с.

У посібнику з позицій системного підходу викладено основні та споріднені геоботанічні терміни й поняття, для деяких наведено детальне тлумачення, математичний апарат, зміст підкріплено ілюстраціями.

Для науковців, викладачів, аспірантів і студентів класичних природничих та аграрних вищих навчальних закладів, усіх, хто цікавиться проблемами геоботаніки. 